\title{
Food Preference of Cavia magna (Rodentia: Caviidae) on a Subtropical Island in Southern Brazil
}

Kelen Rodrigues da Veiga ${ }^{*}$

https://orcid.org/0000-0002-6875-5245

Sônia Marisa Hefler ${ }^{1}$

https://orcid.org/0000-0001-7985-3177

Elton Pinto Colares ${ }^{1}$

https://orcid.org/0000-0002-9387-5839

Ioni Gonçalves Colares ${ }^{1}$

https://orcid.org/0000-0001-8533-6758

1Federal University of Rio Grande - FURG, Postgraduate Program in Biology of Continental Aquatic Environments, Institute of Biological Sciences, Rio Grande, Rio Grande do Sul, Brasil.

Received: 2018.08.30; Accepted: 2019.07.08.

*Correspondence: rveiga.kelen@gmail.com; Tel.: +55-53-98134-1643 (K.R.V.)

\section{HIGHLIGHTS}

- The studied rodent select food items, showing preference for some species.

- The microhistological analysis of feces was used in this research.

- Juncus acutus, Cladium jamaicense and Plantago australis presented the highest IVI.

- Hypoxis decumbens, J. acutus and Paspalum urvillei were the most consumed species.

\begin{abstract}
This study aimed to link the plants consumed by Cavia magna and their availability in the environment, (Ilha dos Marinheiros) determining its food preference. In the environment, 96 species were recorded. Twenty-four plant species were identified in the fecal samples. There wasn't significant difference in the composition of plant species among seasons, although the variation was significant between the island's northern and southern areas concerning the fecal samples. Mantel test's results supported that the availability of vegetation has significant influence on the species consumed. Being that the most consumed species (present on the feces) were distant to their distribution areas, we propose that $C$. magna of Ilha dos Marinheiros actively search and select items to eat, showing food preference for some species.
\end{abstract}

Keywords: Caviidae; estuary; herbivory; rodent; vegetation. 


\section{INTRODUCTION}

One of the first steps in understanding the inner workings of an animal's ecology is to know its diet [1]. The diet depends not only on the quality and abundance of the food in the environment but also on the choice of where to feed, in a cost-benefit relationship [2]. According to Fischer et al. [3], food availability can influence growth, survival, and fecundity rates, resulting in larger individuals in less time. Therefore, the Optimal Foraging Theory (OFT) stipulates that the time spent by the animals to obtain nutrients should be minimized while the amount of energy and nutrients should be enhanced [2].

The feeding habits of herbivores can be studied in several ways. For instance, it is possible to perform studies of feeding habits by direct observation [4] and through the identification of food items by microhistological analyses of feces [5]. The use of the latter technique relies on the fact that plants have non-digestible structures, so it is possible to identify them in the feces [6]. This kind of analysis has been used to define the feeding habit of many herbivores $[7,8,9,10]$.

The genus Cavia Pallas 1766 belongs to the order Rodentia and consists of small rodents commonly called cavies [11]. In southern Brazil, in Rio Grande do Sul State, the only species recorded for this genus are Cavia aperea Erxleben 1777 and Cavia magna Ximenez 1980 [12]. According to Ximenez [13], C. magna is frequently found in formations close to water bodies, in estuaries, and on the edges of lagoons, where the soil is saline.

The genus Cavia is usually composed of solitary animals, active during the early morning and late afternoon [14], when it feeds on various plants [15]. However, individuals of C. magna can be found in hierarchical groups during foraging [16]. It is a monogastric herbivore and depends on the microbial fermentation in the gut [17]. The $C$. magna feces are cylindrical, small, and darkish green color, exhibiting viscous mucus when fresh. Rodents show high fiber digestibility, and of other dietary components, nevertheless, they are used to coprophagy supposedly to obtain a higher nutritional influx in periods of low nutrient dietary [18].

Due to the importance of knowing the diet of an animal, and despite the abundant literature on feeding habits of herbivores at hand, most of them do not quantify the availability of plant species in the foraging site. Verify the spatial distribution of food resource can contribute to a better understanding of animal-plant interaction process. Rodents demonstrate potential for adaptive movements, which influence the ecological variability of habitat [19]. It is possible to presume that the diet selectivity varies according to the characteristics of the environment and that end up affecting the availability of vegetation [20]. The determinants factors of the animal's diet depend on the quality and abundance of food and where the animal foraging occurs, evaluating the cost-benefit of that [2]. In addition, forage herbivores can affect the structure and floristic diversity of their natural habitat [21]. For this reason, it is important to know the availability of food in the environment and the food preferences of the animal under study. Initiatives such as these are necessary, since those factors can influence the development of the species, changing it positively or negatively. In this sense, we intend to elucidate the following questions: 1) Are there spatial or seasonal variations in Ilha dos Marinheiros's vegetation cover display? 2) If there are variations, do they interfere in the diet of Cavia magna? Thus, the goal of our study was to trace a relationship between the plant species found in the diet of $C$. magna and their availability in the environment, to identify this cavy's feeding preferences.

\section{MATERIAL AND METHODS}

\section{Study Site}

Ilha dos Marinheiros is located in Brazil's far south, in the estuary of Lagoa dos Patos (Figure 1), between the coordinates $31^{\circ} 58^{\prime} \mathrm{S}$ and $52^{\circ} 05^{\prime} \mathrm{W}$ and $32^{\circ} 02^{\prime} \mathrm{S}$ and $52^{\circ} 12^{\prime} \mathrm{W}$. Its area is ca. $40 \mathrm{~km}^{2}$ and the vegetation is predominantly composed of grasses, sedges, and rushes, distributed according to flooding and salinity gradients [22]. Along with this gradient, we found populations of Juncus acutus mainly on the shores of Lagoa dos Patos, gradually replaced by populations of Cladium jamaicenses, and interspersed with individuals of 
Hypoxis decumbes, Paspalum urvillei, and Myrsine parvifolia among the island's inward. The climate is mild mesothermic and super-moist. Summer is hot and dry, with an average temperature of $24^{\circ} \mathrm{C}$, while is cold and rainy in the winter, averaging $13^{\circ} \mathrm{C}$. The average annual rainfall is $1,225 \mathrm{~mm}$ [23].

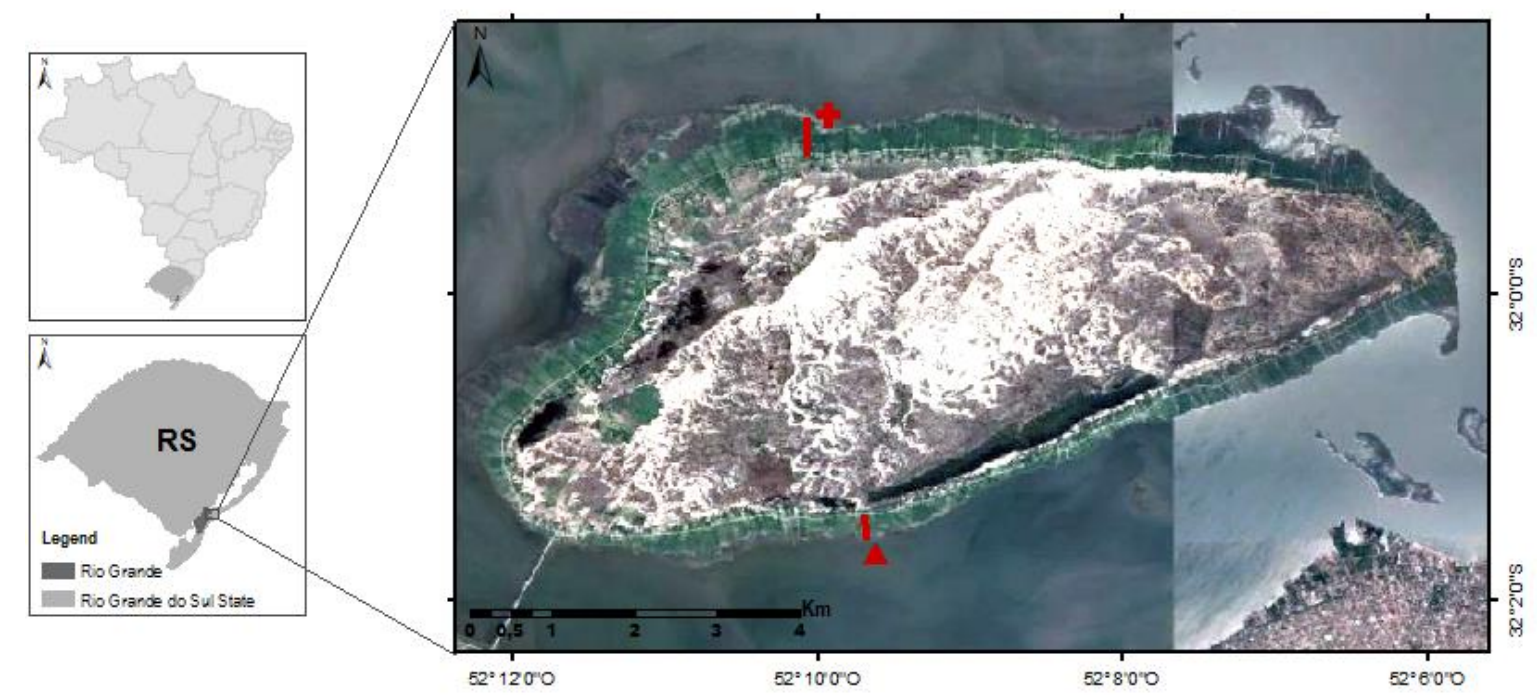

Figure 1. Study site, indicating the two transects in the llha dos Marinheiros, Rio Grande City, State of Rio Grande do Sul - RS. Note: Red Cross: Transect in Northern area; Red Triangle: Transect in Southern area.

\section{Data Collection: Plants and Feces}

Data collection was carried out in two transects, one in the north of the island, reaching $290 \mathrm{~m}$ in length, and the other in the south, totaling $160 \mathrm{~m}$ long. The two transects are $3.5 \mathrm{~km}$ from one another, cut apart by a range of dunes and groups of water bodies, in the island's innermost area (Figure 1). The transects were perpendicular to the road that surrounds the island, starting from it and going towards the shores of the Lagoa dos Patos. This road separates the island's environment into two distinct areas. From the inner side, we find agricultural fields and on the periphery, towards the lagoon, wild vegetation is found. The size of the transects was defined by the area occupied by the wild vegetation. Each transect consisted of ten points, distant from each other in $29 \mathrm{~m}$, in the north, and in $16 \mathrm{~m}$, in the south area. Location of point 01 was the end of the area occupied by the wild vegetation, and point 10 was close to the shore of the lagoon. Three adjacent $1 \mathrm{~m}^{2}$ squares (our sample unit) were fixed perpendicularly to the transect, in each of the ten points, totaling 30 sampling units (SUs) per area.

The vegetation survey was carried out over a year, in four seasonal collections, one for each season (summer, fall, winter, and spring, respectively). All plant species identified in each SUs had their relative coverage recorded by means of a visual estimate, based on the adapted scale Domin-Krajina [24] modified by Garcia and Boldrini [25] as follows: "1" covering up to $5 \%$ of the sampling unit; "2" covering between 6 and $20 \%$; "3" covering between 21 and 40\%; "4" covering between 41 and 60\%; "5" covering between 61 and $80 \%$ and "6" covering between $81 \%$ and $100 \%$. Some samples of vegetation were collected, preserved in $70 \%$ ethanol, and used to create a reference collection for the specie's leaf epidermis. Another subsample was used for assembling herbarium sheets, which were incorporated into the Rio Grande University Herbarium (HURG) collection, as voucher material.

Fecal samples of C. magna were collected in each of the 30 sampling units (SUs), monthly, during a year. The number of fecal samples found was variable, and all the feces samples present in each SUs were collected. Fecal samples were packed in $45 \mathrm{ml}$ Falcon tubes and stored in FAA solution (10\% formalin, $85 \%$ ethanol, and $5 \%$ acetic acid) for further analysis. For the analysis, the samples were grouped seasonally (spring, summer, fall, and 
winter) and for areas (north and south). Sampling units not containing feces were assigned value zero in the assembly of the data matrix.

Bibliography, identification keys, and deliberation with experts allowed for identification of plant species collected. The families were determined following Smith et al. [26] for ferns and the Angiosperm Phylogeny Group - APG III [27] for angiosperms.

The Importance Value Index (IVI) was calculated for species presents in both transects, according to the formula: IVI $(\%)=(R C+R F) / 2$, where $R C$ means the relative coverage and $\mathrm{RF}$ the values of the relative frequency of each plant species [28]. Where $\mathrm{RC}$ was obtained by scale of Domin-Krajina and RF was determined using the ratio of the absolute frequency of a certain species and the sum of the absolute frequencies of the other species [24]. The IVI was calculated in order to numerically express the importance of each species within the plant community.

For the histological analysis of fecal content, the technique developed by Baumgartner and Martin [29] was applied, which consists of comparing the epidermal plant fragments found on the microscope slides prepared from fecal samples with those of the reference collection made from the leaf epidermis of local vegetation. For standardization purposes, five fecal sub-samples were randomly selected for each SUS, which were used in the preparation of five slides for microscopic analysis [5,9]. Microscope slides with fecal contents were examined throughout their length in an Olympus microscope model CX41 (magnification of 20x). In order to analyze the entire length of slides, longitudinal and contiguous field were drawn, writing down the sort of epidermic fragment found and the number of times where it appeared. Anatomical characteristics such as size, type and shape of epidermic cells, presence of cells with silica encrustations, distribution and size of stomata, and hairiness were considered for the identification of plant species present in the animal feces.

The frequency of each food item found in the feces of $C$. magna was calculated according to the formula: $\mathrm{A}(\%)=$ (number fragments of item $i$ / total number of fragments observed) $\times 100$ [5], where $i$ is species. For this calculation, were taken into consideration the sum of fragments of all species identified in the study area (north and south) and for each season separately.

Two matrices were prepared. The first matrix lists the IVI for plant species found on IIha dos Marinheiros in each of the 30 sampling units (SUs) and study areas (northern and southern regions). The second matrix was organized with the frequency of plant species present in the fecal samples of $C$. magna, again for each of the $30 \mathrm{SU}$ and areas. With the first matrix, assembled with the IVI values, it was possible to determine if there were variations in the vegetation cover between the two areas during the four seasons of the year (two-way ANOSIM test, Bray-Curtis distance, 100000 permutations). As for the second matrix, assembled with the frequency of plants present in the fecal samples, the same statistical test was applied, in order to check whether there was variation among the fragments of plant species found in fecal samples from the northern and southern areas, and whether there was seasonal variation in the species consumed. The $P \leq 0.05$ was considered in all analyses.

The application of Mantel's test (5000 permutations, Pearson's coefficient) comparing the two matrices, allowed the search for correlations in the similarity between plant species available in the environment and plant species found in the fecal samples of $C$. magna, considering both the areas and the four seasons of the year. A Correspondence Analysis CA [30] was calculated using the IVI values of the species found in the environment in each sampling unit (SUs) and frequencies of the plant species identified in the feces in each sampling unit, to evaluate possible movements of the animal while seeking for specific plant species. The analysis was repeated for both northern and southern areas. During the plotting of the CA, the sampling units (SUs) were assembled in groups of three, using as a basis the previously established points 01 to 10 along the transects. Thus, the location of the species of plants available in the environment and the species of plants found in the fecal samples were made from the interior of the island (point 01) towards the shore of the Lagoa dos Patos (point 10). All the tests were performed using the software Past, version 2.01. 
The analysis was repeated for both north and south areas, using the following acronyms of species: Cladium jamaicense = A; Cynodon dactylon = B; Dichanthelium dichotomum = C; Galium hypocarpium = D; Hypoxis decumbens = E; Ilex theezans = F; Juncus acutus = G; Myrsine parvifolia $=\mathrm{H}$; Paspalum urvillei $=\mathrm{I} ;$ Plantago australis $=\mathrm{J}$; Psidium cattleyanum $=\mathrm{K}$; Sapium glandulatum $=\mathrm{L}$; Thelyptyeris dentata $=\mathrm{M}$; Tropaeolum pentaphyllum $=\mathrm{N}$.

\section{RESULTS}

Ninety-six species were identified in the environment, distributed in 44 families, during the four sampling periods in both study areas. Among the most abundant families in number of species were Asteraceae (13 spp.), Poaceae (12 spp.), and Cyperaceae (5 spp.). Over all the sampled species, $37.5 \%$ were present in both study areas. The species J. acutus showed the highest IVI in the four seasons in the south. On the other hand, during winter and spring in the north, the species that had the highest rates for the same parameter were $C$. jamaicense and $P$. australis, respectively.

Throughout the four seasons, and in both study areas, the C. magna feces amounted to 132 samples. In the 30 SUs analyzed, 108 had absent fecal samples. The absence of feces between the sampling had a random occurrence, not following any trends seasonal or between the northern and southern areas. A total of 660 microscopic slides of the $C$. magna fecal subsamples were examined, where 26,738 pieces of plant epidermis were identified for both study areas. Twenty-four species belonging to 19 families were identified in the fecal samples. Among these, 14 species of plants were identified in feces samples from both northern and southern areas. Seven species of plants identified in feces samples being exclusive to the north and three exclusive to the south (Table 1). However, $55 \%$ of the identified species showed low consumption, occurring with a frequency of less than $5 \%$ in the feces (Table 1).

Poaceae had the highest number of species ingested, although with little consumption, accounting for $23.5 \%$ of the total species in both areas (Table 1). In turn, Hypoxidaceae $(H$. decumbens) and Juncaceae (J. acutus), were the most ingested plants, accounting for over $66 \%$ of the fragments found for the northern area. Together, these two species, representing the families above, accounted for $5.9 \%$ and $11.9 \%$ of IVI of the species available in the environment, concurrently.

In the southern area, $46 \%$ of total consumption was due to Hypoxidaceae and Poaceae. In the south, $P$. urvillei was the species with the highest frequency in the diet in the four periods. On the other hand, $H$. decumbens was the most frequent species in fecal samples in the northern area during summer, fall and spring. In winter, J. acutus was the most consumed, being the second most frequent consumed species in the same area for the other periods (Table 1).

Table 1. Plant species found on Ilha dos Marinheiros and occurring in the diet of Cavia magna, in both the northern and southern areas and in the four seasons ${ }^{1}$.

\begin{tabular}{|c|c|c|c|c|c|c|c|c|c|}
\hline \multirow{2}{*}{ Species } & \multirow{2}{*}{$\mathbf{P}$} & \multicolumn{4}{|c|}{ North } & \multicolumn{4}{|c|}{ South } \\
\hline & & Su & $\mathbf{F a}$ & Wi & Sp & Su & $\mathbf{F a}$ & Wi & Sp \\
\hline \multicolumn{10}{|l|}{ Aquifoliaceae } \\
\hline \multirow{2}{*}{ Ilex theezans Mart. ex Reissek } & IVI & 3.3 & 3.3 & - & 1.7 & 1.3 & - & - & - \\
\hline & $A$ & 1.0 & 0.8 & - & - & - & - & - & - \\
\hline \multicolumn{10}{|l|}{ Asteraceae } \\
\hline \multirow{2}{*}{ Conyza canadensis (L.) Cronquist } & IVI & 1.8 & - & 1.3 & 1.1 & 1.8 & 2.1 & 3.0 & 3.9 \\
\hline & $A$ & 1.3 & - & 0.1 & 0.2 & 0.5 & 1.9 & 2.2 & 1.0 \\
\hline Hypochaeris brasiliensis (Less.) & IVI & - & - & - & - & - & - & 3.8 & 0.5 \\
\hline
\end{tabular}

${ }^{1} \mathrm{P}=$ Parameters; IVI $(\%)=$ Importance Value Index of the species in the environment; A (\%) = frequency of the item in the fecal sample; $\mathrm{Su}=\mathrm{Summer} ; \mathrm{Fa}=\mathrm{Fall} ; \mathrm{Wi}=\mathrm{Winter} ; \mathrm{Sp}=$ Spring. The most consumed species are highlighted in bold. 


\section{Species
Benth. \& Hook. f. ex Griseb.}

\section{Caprifoliaceae}

Lonicera japonica Thunb.

\section{Commelinaceae}

Commelina erecta L.

\section{Convolvulaceae}

Ipomoea grandifolia (Dammer)

O'Donell

\section{Cyperaceae}

Cladium jamaicense Crantz

\section{Euphorbiaceae}

Sapium glandulatum (Vell.) Pax

\section{Hypoxidaceae}

Hypoxis decumbens $\mathrm{L}$.

\section{Juncaceae}

Juncus acutus L.

\section{Myrtaceae}

Psidium cattleyanum Sabine

\section{Plantaginaceae}

Plantago australis Lam

\section{Poaceae}

Cynodon dactylon (L.) Pers.

Dichanthelium dichotomum (L.) Gould

Paspalum notatum Alain ex Flüggé

Paspalum urvillei Steud.

Polypogon monspeliensis (L.) Desf.

\section{Primulaceae}

Myrsine parvifolia A. DC.

\begin{tabular}{ccccccccc} 
& \multicolumn{4}{c}{ North } & \multicolumn{4}{c}{ South } \\
\cline { 2 - 10 } & Su & Fa & Wi & Sp & Su & Fa & Wi & Sp \\
\hline A & - & - & - & - & - & - & 0.3 & -
\end{tabular}

IVI $\quad 3.0 \quad-\quad-\quad 0.8$

A $\quad 0.7 \quad-\quad-\quad-0.2$

$\begin{array}{lllll}\text { IVI } & 0.7 & - & 0.4 & 0.3\end{array}$

A $\quad 0.3 \quad-\quad 0.1 \quad-$

0.1

$$
\begin{array}{lllllllll}
\mathrm{IVI} & - & - & - & - & 1.3 & 0.8 & - & 1.0 \\
\mathrm{~A} & - & - & - & - & 0.2 & - & - & 0.2
\end{array}
$$

$\begin{array}{ccccccccc}\text { IVI } & 4.5 & 7.6 & 10.8 & 6.3 & 4.6 & 8.3 & 13.0 & 8.4 \\ \text { A } & 4.8 & 1.6 & 1.5 & 0.5 & 1.2 & 0.8 & 0.3 & 0.4\end{array}$

$\begin{array}{llllll}\mathrm{IVI} & - & 3.5 & 2.5 & 0.8 & 1.7 \\ \mathrm{~A} & - & 5.5 & 1.6 & 0.1 & -\end{array}$

$\begin{array}{lllllllll}\text { IVI } & 6.8 & 4.8 & 6.2 & 6.0 & 7.1 & 5.6 & 4.9 & 7.2\end{array}$

$\begin{array}{lllllllll}\text { A } & 36.6 & 33.1 & 31.7 & 42.7 & 20.3 & 13.2 & 5.1 & 16.7\end{array}$

$\begin{array}{lllllllll}\text { IVI } & 17.8 & 13.2 & 8.5 & 7.8 & 28.0 & 25.1 & 22.1 & 12.7\end{array}$

$\begin{array}{lllllllll}\text { A } & 27.9 & 22.7 & 35.2 & 36.7 & 4.7 & 3.1 & 7.7 & 7.5\end{array}$

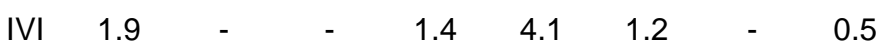

$\begin{array}{llllllllll}\text { A } & 1.3 & - & - & 0.5 & 0.4 & 1.9 & - & 0.5\end{array}$

$\begin{array}{lllllllll}\text { IVI } & 8.6 & 9.2 & 9.8 & 8.6 & - & - & 0.7 & 1.6\end{array}$

$\begin{array}{lllllllllll}\mathrm{A} & - & - & 0.8 & 0.2 & - & - & - & 0.5\end{array}$

$\begin{array}{llllllll}\text { IVI } & 2.6 & 3.8 & 3.6 & 1.5 & - & - & -\end{array} 4.2$

$\begin{array}{lllllllll}\text { A } & 2.7 & 0.8 & 8.4 & 3.1 & 0.2 & - & 2.0 & -\end{array}$

$\begin{array}{lllllllll}\text { IVI } & - & - & 3.3 & 1.1 & 2.7 & 0.8 & 3.0 & 0.5\end{array}$

$\begin{array}{lllllllll}\mathrm{A} & - & - & 0.2 & 0.2 & 2.4 & 0.6 & 0.4 & -\end{array}$

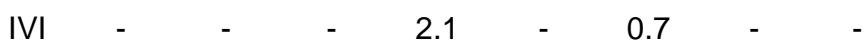

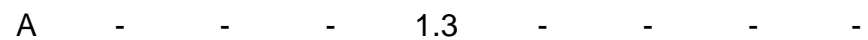

$\begin{array}{lllllllll}\text { IVI } & 3.1 & 2.9 & 0.4 & - & 12.5 & 4.3 & 13.9 & 3.3\end{array}$

$\begin{array}{lllllllll}\text { A } & 3.5 & 4.9 & - & - & 30.7 & 30.8 & 29.2 & 29.7\end{array}$

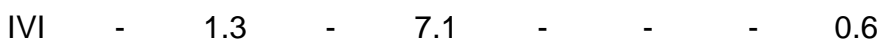

$\begin{array}{llllllllll}\mathrm{A} & - & 0.4 & - & 0.7 & - & - & - & & 0.7\end{array}$

$\begin{array}{lllllllll}\text { IVI } & 7.3 & 7.3 & 7.6 & 1.9 & 6.8 & 11.1 & 5.0 & 6.0\end{array}$ 


\begin{tabular}{|c|c|c|c|c|c|c|c|c|c|}
\hline \multirow{3}{*}{ Species } & \multirow{2}{*}{$\mathbf{P}$} & \multicolumn{4}{|c|}{ North } & \multicolumn{4}{|c|}{ South } \\
\hline & & Su & $\mathbf{F a}$ & $\mathbf{W i}$ & Sp & Su & $\mathrm{Fa}$ & Wi & Sp \\
\hline & $A$ & 2.6 & 0.9 & 4.9 & 0.9 & 6.0 & 5.5 & 3.6 & 2.6 \\
\hline \multicolumn{10}{|l|}{ Pteridaceae } \\
\hline Acrostichum danaeifolium Langsd. \& & IVI & - & - & - & - & - & 1.9 & 2.3 & - \\
\hline Fisch. & $A$ & - & - & - & - & - & - & 0.3 & - \\
\hline \multicolumn{10}{|l|}{ Rubiaceae } \\
\hline Galium hypocarpium (L.) Endl. ex & IVI & - & 0.5 & 4.3 & 2.0 & - & - & - & - \\
\hline Griseb. & A & - & 2.1 & 0.1 & - & - & - & - & - \\
\hline \multicolumn{10}{|l|}{ Smilacaceae } \\
\hline \multirow{2}{*}{ Smilax campestris Griseb. } & IVI & 0.7 & 2.3 & - & 1.6 & 1.7 & 0.8 & 2.3 & 1.0 \\
\hline & $A$ & - & - & 0.2 & - & - & 0.3 & - & - \\
\hline \multicolumn{10}{|l|}{ Thelypteridaceae } \\
\hline Thelypteris dentata (Forssk.) E.P. St. & IVI & 1.3 & 3.3 & - & 0.3 & - & - & - & - \\
\hline John & A & 0.1 & - & - & 0.7 & - & - & - & - \\
\hline \multicolumn{10}{|l|}{ Tropaeolaceae } \\
\hline \multirow{2}{*}{ Tropaeolum pentaphyllum Lam. } & IVI & 1.5 & 0.6 & 0.9 & 0.3 & - & - & 2.3 & 1.7 \\
\hline & A & 0.6 & 1.1 & 0.7 & - & - & - & 1.9 & 2.5 \\
\hline \multicolumn{10}{|l|}{ Vitaceae } \\
\hline \multirow{2}{*}{ Vitis sp. L. } & IVI & - & 1.1 & 1.0 & 2.4 & - & - & - & - \\
\hline & $A$ & - & - & 0.1 & - & - & - & - & - \\
\hline
\end{tabular}

Regarding the relative plant species coverage in the environment, most of the species were present in the two study areas, north and south of the Ilha dos Marinheiros, with no significant differences $\left(p=0.07, R^{2}=0.01\right)$. In the seasonal analysis of the relative species coverage, a significant difference to the coverage percentage of those species on the environment $\left(p=0.005 ; R^{2}=0.07\right)$, and the species where replaced throughout the year, showing a significant difference between the seasons.

A similar result was observed in the analysis of feces, where there were no significant differences in the composition of plant species present in the feces of $C$. magna $\left(p=0.07, R^{2}\right.$ $=0.01$ ) between the northern and southern areas of the Ilha dos Marinheiros, though composition of the vegetation in the feces has varied significantly between seasons $(p=$ $\left.0.001 ; R^{2}=0.2\right)$. Juncus acutus, $C$. jamaicense, and $P$. urvillei were the species with the highest contribution to the variability between sites, corresponding to $41 \%$ of the total. The results of the Mantel test showed a significant and positive association $(P=0.004)$, although with low correlation $\left(R^{2}=0.12\right)$ between the composition of species found in fecal samples and the relative species coverage found in the environment.

For the results of the CA, we can see that there was a similar distribution of vegetation between the two study sites (Figure. 2a), complementing the results obtained by ANOSIM test. With respect to vegetation identified in feces (Figure. $2 b$ ), the CA shows a separation of food items consumed by the animals between the two study areas. 


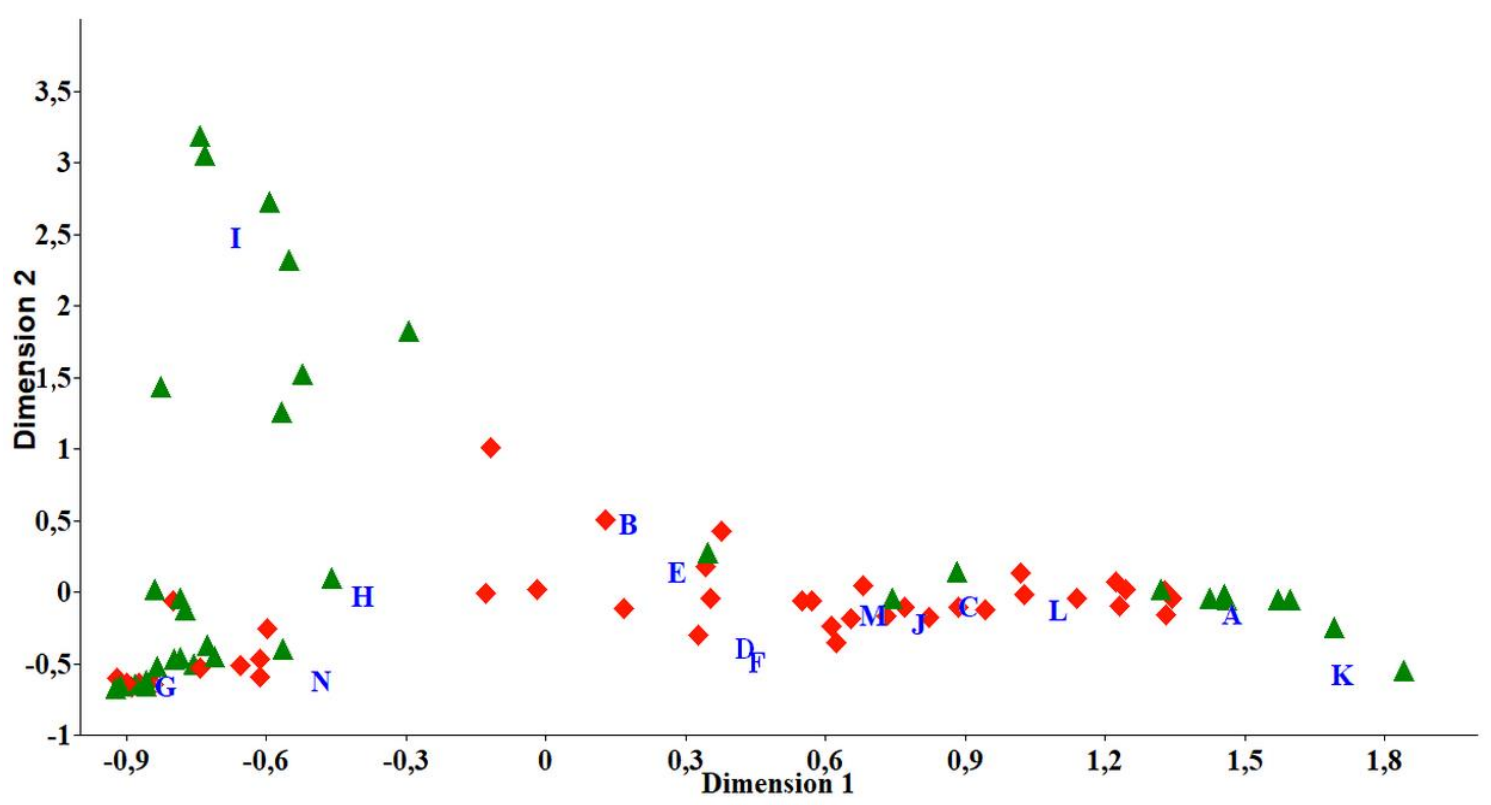

(a)

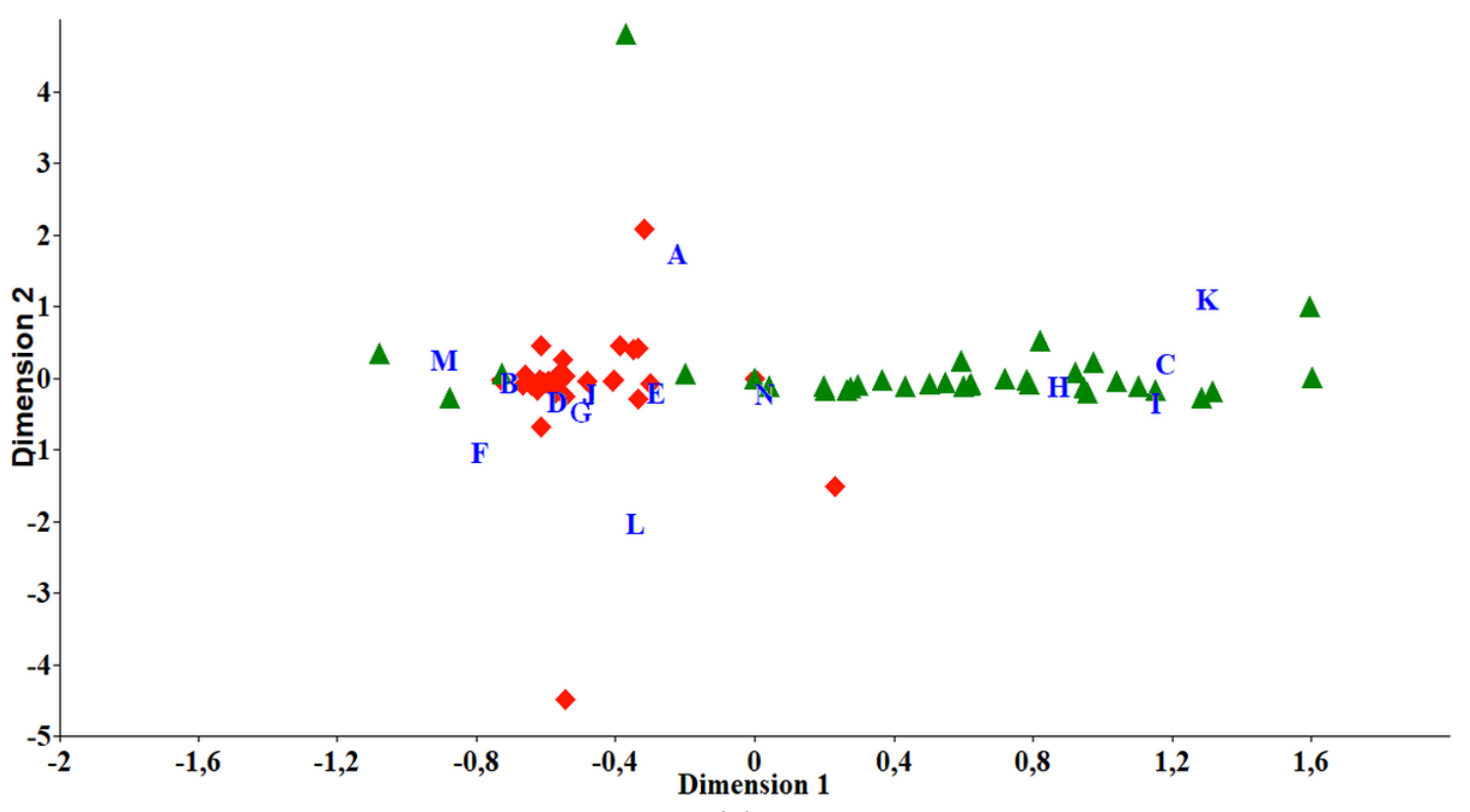

(b)

Figure 2. Correspondence analysis (CA) for the Northern and Southern areas of Ilha dos Marinheiros with the plant species' arrangement found in: (a) the environment and (b) the fecal samples of Cavia magna. Note: The 1 and 2 dimensions represent the distribution of the species on the collection points; Red Diamond: Northern area; Green Triangle: Southern area. For graphic effect, we included only those species consumed with frequency of occurrence $>5 \%$. Acronyms of species: Cladium jamaicense = A; Cynodon dactylon = B; Dichanthelium dichotomum = C; Galium hypocarpium = D; Hypoxis decumbens = E; Ilex theizans = F; Juncus acutus = G; Myrsine parvifolia = H; Paspalum urvillei = I; Plantago australis = J; Psidium cattleyanum = K; Sapium glandulatum $=\mathrm{L}$; Thelypyeris dentata $=\mathrm{M} ;$ Tropaeolum pentaphyllum $=\mathrm{N}$.

When we separated the samples from the two study sites, the results of CA showed variability between plant species' locations available in the samples units (SUs) in the environment and the points where these same species were identified in the fecal samples, along the transects. In the north, the species J. acutus, found at points 8, 9, and 10 in the environment (Figure.3a), was identified in feces collected in sections 6 to 8 , as well as at points 1 and 2, approximately $200 \mathrm{~m}$ away from the place of occurrence of the species (Figure.3b), showing that the animal moved about to consume it. 


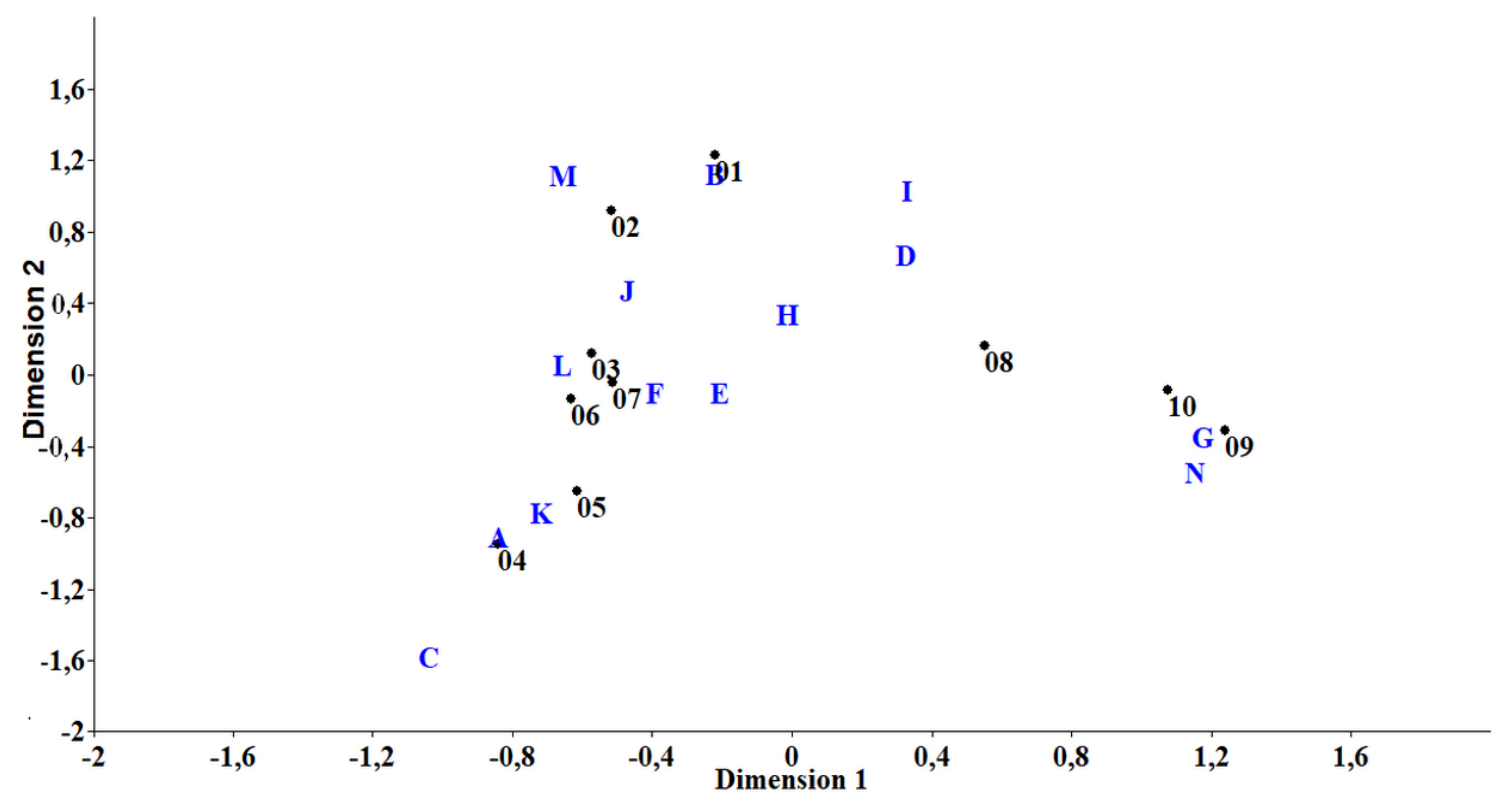

(a)

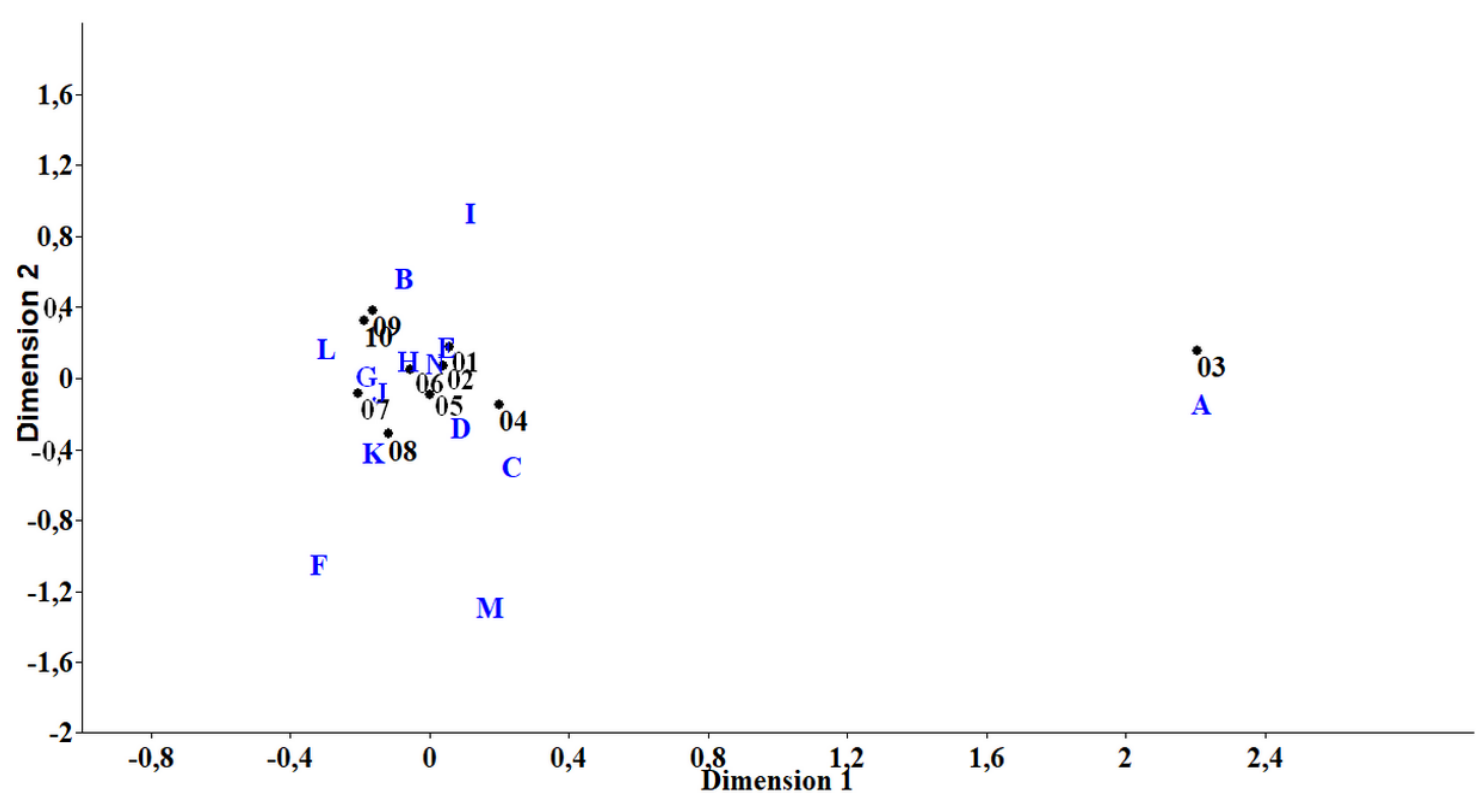

(b)

Figure 3. Correspondence analysis (CA) with the plant species' arrangement found in: (a) the environment and (b) the feces, in relation to the SUs for the Northern area of Ilha dos Marinheiros. Note: The 1 and 2 dimensions represent the distribution of the species on the collection points; numbers represent the sampling units (SUs); letters represent the plant species. For graphic effect, we included only those species consumed with frequency of occurrence $>5 \%$. Acronyms of species: Cladium jamaicense = $\mathrm{A} ;$ Cynodon dactylon = B; Dichanthelium dichotomum = $\mathrm{C} ; \mathrm{Galium}$ hypocarpium = D; Hypoxis decumbens = E; Ilex theizans = F; Juncus acutus = G; Myrsine parvifolia = $\mathrm{H}$; Paspalum urvillei = I; Plantago australis = J; Psidium cattleyanum = K; Sapium glandulatum $=\mathrm{L}$; Thelypyeris dentata $=\mathrm{M}$; Tropaeolum pentaphyllum $=\mathrm{N}$.

Similarly, in the south, $P$. urvillei had its distribution at points 1 and 2 in the environment (Figure.4a) and was identified in fecal samples at points 9 and 10, approximately $120 \mathrm{~m}$ from the place of occurrence (Figure.4b), showing this variation and movement for the consumption of the species in this study. 


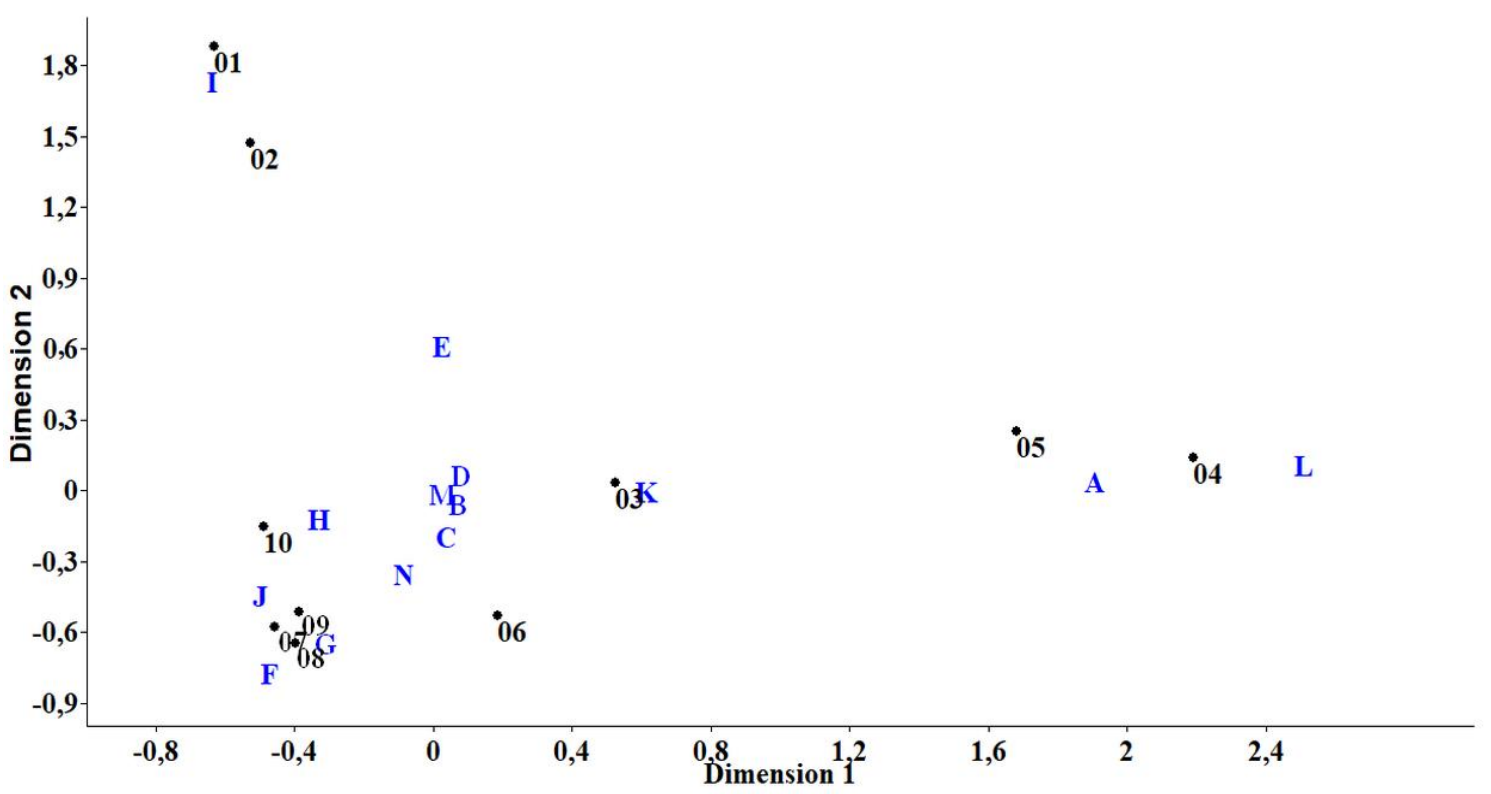

(a)

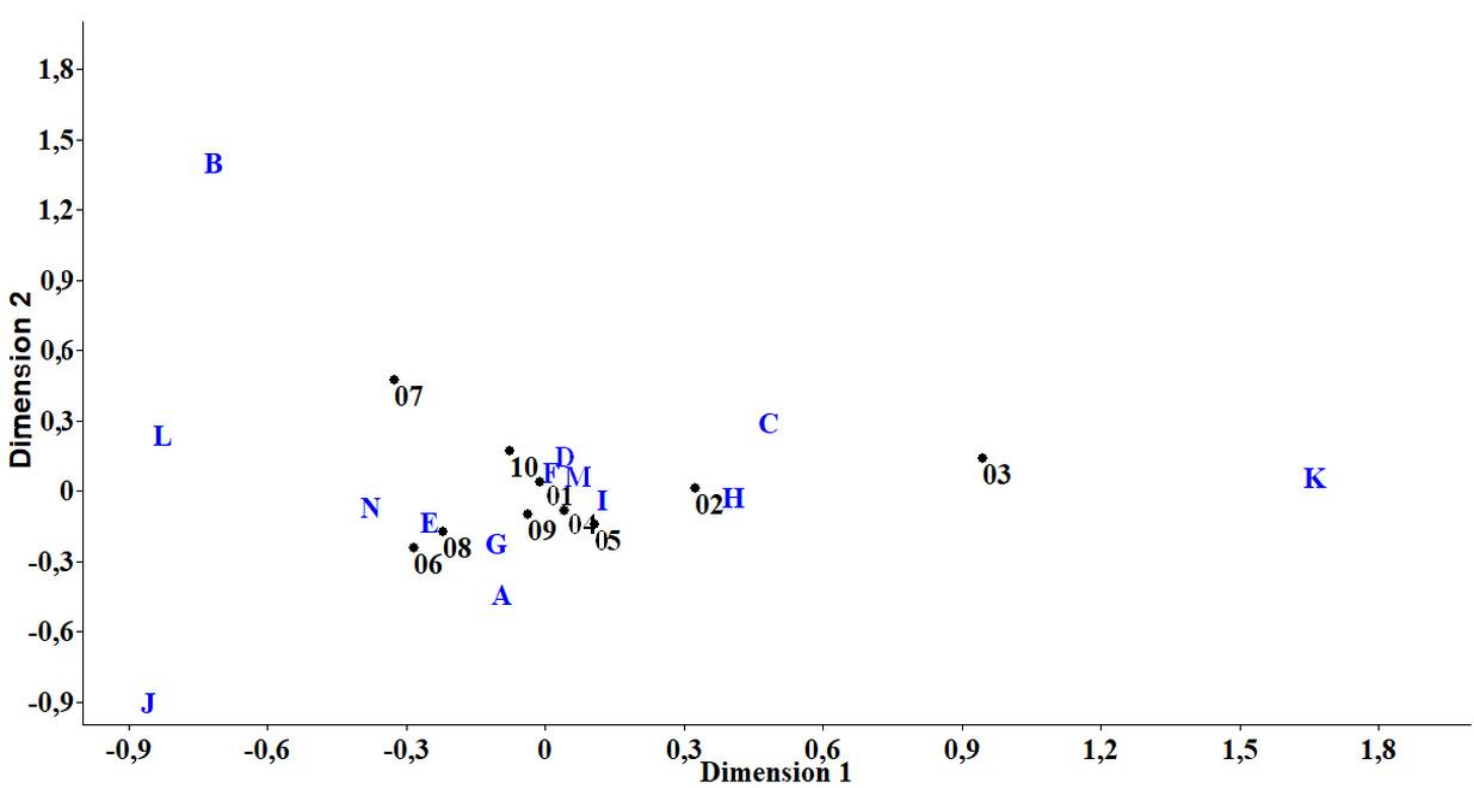

(b)

Figure 4. Correspondence analysis (CA), with the plant species' arrangement found in: (a) the environment and (b) the feces, in relation to the SUs for the Southern area of Ilha dos Marinheiros. Note: The 1 and 2 dimensions represent the distribution of the species on the collection points; numbers represent the sampling units (SUs); letters represent the plant species. For graphic effect, we included only those species consumed with frequency of occurrence $>5 \%$. Acronyms of species: Cladium jamaicense = A; Cynodon dactylon = B; Dichanthelium dichotomum = C; Hypoxis decumbens = E; Ilex theizans = F; Juncus acutus = G; Myrsine parvifolia = H; Paspalum urvillei = I; Plantago australis = J; Psidium cattleyanum = K; Sapium glandulatum $=\mathrm{L} ;$ Tropaeolum pentaphyllum $=\mathrm{N}$.

\section{DISCUSSION}

The profusion displayed by Asteraceae, Poaceae, and Cyperaceae families throughout the four seasons, combined with the abundances of $J$. acutus and $P$. australis in the two areas of Ilha dos Marinheiros can be explained by means for favorable adaptability of these taxa to the estuarine environment [29], where this study took place. Some species, such as $C$. jamaicense, showed variations in their IVI over the year, being replaced by other species. 
Even so, the test indicated that the environment's plant species composition showed no significant variations either among the seasons or between the areas, attesting a similar environment. Furnari's [4] study also found the families Poaceae and Asteraceae as more numerous in the diet of $C$. intermedia, although the use of different techniques applied in that particular research. Despite the wide range of vegetation available on Ilha dos Marinheiros, only 24 species were identified in fecal samples of $C$. magna. Furthermore, not only was the number of consumed species lower than the environmental supply, but also most of the species exhibit low occurrence frequency $(\sim 1 \%)$ in fecal content. Borges and Colares [7] studied the diet of capybaras and confirmed that plants found at low frequency (1\%) in the fecal samples may have been ingested accidentally, or possibly randomly consumed. However, in this study, the quantification of plant species, along with their location in the transects, allowed us to highlight the availability of this vegetation, although the consumption of some species was reduced, indicating a possibly active search for a different number of plant species by the cavy. Furnari [4], observing the behavior of Cavia intermedia, also noted that the animal's search for certain species to feed, while avoiding predators, with dietary variations, changed according to the foraging site and the season of the year.

According to Prigioni et al. [20], the selectivity of an animal's diet varies according to the environmental conditions and characteristics of each region. As the study site was characterized in a similar environment, this may have caused the low variability in the number of species present in the diet of $C$. magna. However, when comparing both areas, an increased intake of some species was noticeable, such as $C$. dactylon, which was five times more consumed in the north than in the south. Also, some species were consumed in only one of the sites studied, such as Galium hypocarpium, ingested only in the north. These differences contributed to the variation among species consumed in the both areas. The significant difference between north and south regarding the consumption of plant species by $C$. magna can be better attributed to individual characteristics of the population rather than the environment's food supply, or it might characterize the presence of distinct populations. The location of the two study areas, about $3.5 \mathrm{~km}$ from one another and separated by an open area of dunes and small water bodies, can be a determining factor for the occurrence of distinct populations at the study site.

The family Hypoxidaceae has not been reported before in studies of herbivore diet. Hypoxis decumbens was present throughout both areas, in all the four seasons, but in low abundance. Some species of the genus Hypoxis have a large amount of carbohydrates and linoleic acids in their leaves [31]. Furthermore, Kinupp and Barros [32] found that the rhizomatous structure of $H$. decumbens has a high content of protein, phosphorus, and zinc. According to Benevenga et al. [33], these elements are necessary for the rodent's metabolism, encouraging its consumption. Thus, the increased demand for this species may indicate the need for supplemental feeding, or the cavy's preference for this plant.

Regarding the number of species present in the diet of $C$. magna, in both areas, the Poaceae family was notoriously the most abundant. Other authors also reported that Poaceae was the family with most species found in capybara [34], coypu [9], and cavy's [4] diet. These authors attributed the greater number of Poaceae species in the herbivore diet to their nutritional quality and environmental availability, even when, differently from our study, no quantification and distribution analysis of vegetation was performed in that work for that connection to be established. The environment's quantification and distribution of vegetation, such as we did in our study, allowed us to confirm the selective search and intake of family Poaceae species for the studied animals.

The genus Paspalum has various species present in herbivores' diet [35]. According to Pozzobon and Valls [36], in southern Brazil this genus species are known for their higher quality of forage when compared with another grasses. Borges and Colares [7], Rickli and Reis [37], Colares et al. [9], and Furnari [4] found in their diet studies of other rodents, that the species of the genus Paspalum are the most consumed in at least one period analyzed. In our study we also found high abundance of fragments of $P$. urvillei in $C$. magna feces. Paspalum urvillei provides high nutritional content and when young has great palatability and low fiber content [38], being more easily digested. In addition, it allows a better detection of the predator approach, which also may explain the large consumption by $C$. magna. 
The $P$. urvillei occurrence was scattered throughout the southern area, with the highest frequency at sampling points 1 and 2 . However, the species was identified in fecal samples near the sampling sites and in distant areas, such as at sampling point 10, approximately $120 \mathrm{~m}$ apart. Similarly, the high frequency of J. acutus in C. magna's fecal samples occurred over the entire northern area, with a displacement around $200 \mathrm{~m}$, and not only where the species was most abundant (near Lagoa dos Patos). Cassini [39] stated that although the animals normally feed in areas close to one each other, it is possible that they move to more distant areas, increasing time of food consumption compared to the time spent walking. Thus, in this conjecture we can support that the presence of $P$. urvillei and $J$. acutus in $C$. magna's diet occurred by choice and that the animal actively sought this food items in both southern and northern areas, respectively. The distance between the points where the vegetation was observed in the environment and where the fecal samples were collected make us believe that the animal moved specifically seeking for these species.

According to Begon et al. [40], the greater time expended to consume one species is advantageous when this is abundant in the foraging site, contribute to explain the behavior recorded for cavy in this study. This active movement is in agreement with the OFT, which proposes that the food items selected must have a high energy content [41]. The higher travel time leads to fewer trips in food search. The energy spent in the search is offset, and the exposure risk to predation, need to be compensated by the energy content of the item ingested [41], this equally can explain the displacements made by $C$. magna, in search of the most consumed species.

Parsons and De la Cruz [42] found a large amount of potassium, calcium, magnesium, and amino acids such as glutamic acid and proline in the Juncus leaves, with the concentration increasing along the leaf blades, which may also account for its wide use by cavies in the northern area of Ilha dos Marinheiros. In addition, Chu et al. [43] found that there is an increase in proline concentrations in plants at lower temperatures, which may be the cause of an increase in $J$. acutus consumption, during the winter, in the North.

The $C$. magna preferences for some plant species was corroborated with the results obtained by the Mantel's test. In general, based on the distribution of the plant and where the feces were collected, we can suggest that some species present in small amounts (less than $1 \%$ ) in both areas may have been consumed at the same place. On the other hand, the species with the highest consumption, in the two areas of Ilha dos Marinheiros, were either sought by cavy at greater distances, or were selected by the animal. Even where there was a small supply, was noted a massive consumption of some species, such as with $H$. decumbens.

As observed in this study, despite the abundance of available vegetal species in the environment, $C$. magna chose a few as the main food resource. The quantification of consumed species is most common in captivity experiments [44]. However, the methodology used in our study, with quantification and distribution of vegetation in the environment, proved to be an important tool to be used in demonstrating the feeding preference of $C$. magna without interfering in the habits of the species, having the potential to be used for future studies with other herbivores.

\section{CONCLUSION}

Poaceae was the richest family in number of species present in Cavia magna's diet on the llha dos Marinheiros. The analysis showed the preference for the consumption of plants, such as Paspalum urvillei, Juncus acutus and Hypoxis decumbens, with active search of $C$. magna for these species, in distant points of their distribution. The methodology used, comparing the distribution of the plants in the environment, with the location where the feces were collected, favored the verification of this search behavior for specific food items.

Funding: This research was funded by Fundação de Coordenação e Aperfeiçoamento de Pessoal de Nível Superior (CAPES).

Acknowledgments: We thank the University for the logistical support. Caroline Igansi, Guilherme Ceolin and Marilia Costa, for their help in plant species identification, during fieldwork and laboratory activities. 
Conflicts of Interest: The authors declare no conflict of interest.

\section{REFERENCES}

1. Sih A, Christensen B. Optimal diet theory: when does it work, and when and why does it fail? Anim Behav. 2001;61:379-90.

2. Torres-Contreras H, Bozinovic F. Food Selection in an Herbivorous Rodent: Balancing Nutrition with Thermoregulation. Ecology. 1997;78(7):2230-7.

3. Fischer ML, Costa LCM, Nering IS. Utilização de recursos alimentares presentes no ambiente antrópico pelo caramujo gigante africano Achatina fulica Bowdich, 1822: subsídios para o manejo. Bioikos. 2008;22(2):91-100.

4. Furnari N. Comportamento e organização social do preá Cavia intermedia, uma espécie endêmica das llhas Moleques do Sul, Santa Catarina [Tese de Psicologia Experimental]. São Paulo (SP): Universidade de São Paulo; 2011 [cited 2018 Jul 21]. Available from: https://www.teses.usp.br/teses/disponiveis/47/47132/tde-16042012-153100/publico/furnari_do. pdf.

5. Abbas A. Feeding strategy of coypu (Myocastor coypus) in central western France. J Zool. 1991; 224:385-401.

6. Perazzolo M, Pastorini L, Pereira CMP, Görgen AUG. Identificação de Halófitas Secretoras Presentes na Dieta de Herbívoros de uma Marisma da Lagoa dos Patos - RS. Biotemas. 2000;13(2):7-22.

7. Borges LV, Colares IG. Feeding Habits of Capybaras (Hydrochoerus hydrochaeris, Linnaeus 1766), in the Ecological Reserve of Taim (ESEC - Taim) - South of Brazil. Braz Arch Biol Techn. 2007;50(3):409-16.

8. López-Cortés F, Cortés A, Miranda E, Rau JR. Dieta de Abrothrix andinus, Phyllotis xanthopygus (Rodentia) y Lepus europaeus (Lagomorpha) em un ambiente alto andino de Chile. Rev Chil Hist Nat. 2007;80(1):3-12.

9. Colares IG, Oliveira RNV, Oliveira RM, Colares EP. Feeding habits of coypu (Myocastor coypus Molina 1978) in the wetlands of the Southern region of Brazil. An Acad Bras Cienc. 2010;82(3):671-8.

10. Espinelli FP, Corrêa F, Colares EP, Colares IG. The partitioning of food resources between two rodents in the subtropical region of southern Brazil. An Acad Bras Cienc. 2017;89(1):191-202.

11. Cherem JJ, Olimpio J, Ximenez A. Descrição de uma nova espécie do gênero Cavia Pallas, 1766 (Mammalia - Caviidae) das Ilhas dos Moleques do Sul, Santa Catarina, Sul do Brasil. Biotemas.1999;12(1):95-117.

12. Gava A, Santos MB, Quintela FM. A new karyotype for Cavia magna (Rodentia: Caviidae) from an estuarine island and $C$. aperea from adjacent mainland. Acta Theriol. 2012;57:9-14.

13. Ximenez A. Notas sobre el género Cavia Pallas con la descripción de Cavia magna sp. (Mammalia - Caviidae). Rev Nordest Biol. 1980; 3:145-79.

14. Kraus $C$, Thomson L, Kunkele J, Trillmich F. Living slow and dying young? Life-history strategy and age-specific survival rates in a precocials mall mammal. J Anim Ecol. 2005; 74:171-80.

15. Silva F. Mamíferos Silvestres do Rio Grande do Sul. 2nd ed. Porto Alegre (Brasil): Fundação Zoobotânica do Rio Grande do Sul; 1994.

16. Santos EA. Comportamento e organização social do preá Cavia magna (Rodentia: Caviidae) [dissertation]. São Paulo (SP): Universidade de São Paulo; 2013 [cited 2018 Jul 23]. Available from: http://www.teses.usp.br/teses/disponiveis/47/47132/tde-31032014-112740/pt-br.php.

17. Engelhardt W. Absorption of short-chain fatty acids from the large intestine. In: Physiological and Clinical Aspects of Short-Chain Fatty Acids. Cummings JH, Rombeau JL, Sakata T, editors. Cambridge (United Kingdom): Cambridge University Press; 1995. p. 149-70.

18. Sakaguchi E, Nabata A. Comparison of fibre digestion and digesta retention time between nutrias (Myocaster coypus) and guinea-pigs (Cavia porcellus). Comp Biochem Phys. 1992; 3:601-4.

19. Morris DW, Mac Eachern JT. Active Density-dependent Habitat Selection in a Controlled Population of Small Mammals. Ecol. 2010;91(11):3131-7. 
20. Prigioni C, Balestrieri A, Remonti L. Food habits of the coypu, Myocastor coypus, and its impact on aquatic vegetation in a freshwater habitat of NW Italy. Folia Zool. 2005;54(3):269-77.

21. Asquith NM, Wright SJ, Claus MJ. Does mammal community composition control recruitment in neotropical forests? Evidence from Panama. Ecology. 1997;78(3):941-6.

22. Tagliani C, Tagliani P, Costa A, Polette M, Salas E, Asmus M, Oliveira R, Chaves D, Leitzke C. Proposta de Plano de Manejo Ambiental da llha dos Marinheiros - Rio Grande, RS; 2006.

23. Nimer E. Climatologia do Brasil. 2nd ed. Rio de Janeiro (Brasil): Secretaria de Planejamento e Coordenação da Presidência da República, IBGE/DGC/DERNA; 1989.

24. Mueller-Dombois D, Ellenberg H. Aims and methods of vegetation ecology. New York (USA): Willey and Sons; 1974.

25. Garcia E, Boldrini I. Fitossociologia de um campo modificado da Depressão Central do RS. Iheringia S Botan. 1999;(52):23-34.

26. Smith AR, Pryer KM, Schuettpelz E, Korall P, Schneider H, Wolf PG. A classification for extantferns. Taxon. 2006;55(3):705-31.

27. APG III. An update of the Angiosperm Phylogeny Group classification for the orders and families of flowering plants: APG III. Bot J Linn Soc. 2009; 161:105-21.

28. Munhoz CBR, Araújo GM. Métodos de amostragem do estrato herbáceo-subarbustivo. In: Fitossociologia no Brasil: métodos e estudos de casos. Felfili JM, Eisenlohr PV, Melo MMRF, Andrade LA, Neto JAAM, editors. Viçosa (Brasil): Publisher; 2013. p. 213-30.

29. Baumgartner LL, Martin AC. Plant histology as an aid in squirrel food-habit studies. J Wildlife Manage. 1939;3(3):266-8.

30. Hill MO. Reciprocal averaging: an eigenvector method of ordination. J Ecol. 1973; 61:237-49.

31. Nicoletti M, Galeffi C, Messana L, Marini-Bettolo GB. Hypoxidaceae. Medicinal uses and the norlignan constituents. J Ethnopharmacol.1992;36:95-101.

32. Kinupp VF, Barros IBI. Protein and mineral contents of native species, potential vegetables and fruits. Cienc Tecnol Alime. 2008;28(4):846-57.

33. Benevenga JN, Calvert C, Eckhert CD, Fahey GC, Greger JL, Keen CL, Knapka JJ, Magalhaes $\mathrm{H}$, Oftedal OT. Nutrient Requirements of Laboratory Animals. 4th ed. Washington (USA): National Academy Press; 1995.

34. Forero-Montaña J, Betancur J, Cavelier J. Dieta del capybara Hydrochaeris hydrochaeris (Rodentia: Hydrochaeridae) en Caño Limón, Arauca, Colombia. Rev Biol Trop. 2003;51(2):571-8.

35. Desbiez ALJ, Alvarez JM, Santos SA, Cavalcanti MJ. DELTADIET: Guia para Identificação da Dieta de Herbívoros Usando o Sistema DELTA [CD-ROM]. Corumbá (Brasil): Embrapa Pantanal; 2006. 1 CD-ROM.

36. Pozzobon MT, Valls FM. Chromosome Number in Germplasm Accessions of Paspalum notatum (Gramineae). Braz J Genet. 1997;20(1):29-34.

37. Rickli RI, Reis NR. Dieta de "capivaras" - Hydrochaeris hydrochaeris (Linnaeus, 1766) (Mammalia, Rodentia, Caviidae) - em um fragmento florestal em Londrina, PR, Brasil. In: Ecologia de Mamíferos. Reis NR, Peracchi AL, Santos G, editors. Londrina (Brasil):Technical Books; 2008. p. 113-22.

38. Burkart A. Flora ilustrada Entre Rios (Argentina). Part II. Gramíneas. Buenos Aires (Argentina): Collección Científica del INTA; 1969.

39. Cassini $\mathrm{MH}$. Foraging under predation risk in the wild guinea pig Cavia aperea. Oikos. $1991 ; 62(1): 20-4$.

40. Begon M, Townsend CR, Harper JL. Ecology: From individuals to ecosystems. 4th ed. Oxford (United Kingdom): Blackwell Publishing; 2006.

41. Chaves FG, Alves, MAS. Teoria do Forrageamento Ótimo: Premissas e Críticas em Estudos com Aves. Oecologia Australis. 2010;14(2):369-80.

42. Parsons KA, De La Cruz AA. Energy Flow and Grazing Behavior of Conocephaline Grasshoppers in a Juncus roemerianus marsh. Ecology. 1980;61(5):1045-50.

43. Chu TM, Aspinall D, Paleg LG. Stress Metabolism. VI. Temperature Stress and the Accumulation of Proline in Barley and Radish Aust. J Plant Physiol. 1974;1:87-97. 
44. Berchielli TT, Oliveira SG, Garcia AV. Aplicação de técnicas para estudos de ingestão, composição da dieta e digestibilidade (Application of techniques for intake, diet composition and digestibility studies). Arch Veterin Science. 2005;10(2):29-40.

(C) 92018 by the authors. Submitted for possible open access publication
under the terms and conditions of the Creative Commons Attribution (CC
BY NC) license (https://creativecommons.org/licenses/by-nc/4.0/). 